\title{
ZN(II)/AU(I) AND ZN(II)/AG(I) COMPLEXES WITH SALEN SCHIFF BASE EXPRESS PROMISING CYTOTOXIC ACTIVITY IN HUMAN CANCER CELLS
}

\section{TANYA ZHIVKOVA ${ }^{1}$, GABRIELA MARINESCU ${ }^{2 *}$, LORA DYAKOVA ${ }^{3}$, DANIELA CRISTINA CULITA ${ }^{2}$, ROSSEN SPASOV ${ }^{4}$, PAVEL MITRENGA ${ }^{5}$, RENI KALFIN ${ }^{3}$, LUMINITA PATRON ${ }^{2}$, RADOSTINA ALEXANDROVA ${ }^{1 *}$}

\author{
${ }^{1}$ Department of Institute of Experimental Morphology, Pathology and Anthropology with Museum, Bulgarian Academy of Sciences, \\ Sofia, Bulgaria. 'Department of Institute of Physical Chemistry “Ilie Murgulescu," Romanian Academy, Bucharest, Romania. \\ ${ }^{3}$ Department of Institute of Neurobiology, Bulgarian Academy of Sciences, Sofia, Bulgaria. ${ }^{4}$ Department of Faculty of Medicine, \\ Sofia University “St. Kliment Ohridski," Sofia, Bulgaria. ${ }^{5}$ BB - NCIPD Ltd., Sofia, Bulgaria. \\ Email: gabriela_marinescu02@yahoo.com/rialexandrova@hotmail.com
}

Received: 10 July 2018, Revised and Accepted: 07 December 2018

ABSTRACT

Objective: The aim of our study was to evaluate the influence of two complexes of $\mathrm{Zn}(\mathrm{II}) / \mathrm{Au}(\mathrm{I})$ and $\mathrm{Zn}(\mathrm{II}) / \mathrm{Ag}(\mathrm{I})$ with Schiff base ligand ( $\mathrm{H}_{2} \mathrm{Salen}$ ) obtained from the condensation reaction between salicylaldehyde and ethylenediamine (abbreviated ZnSalenAu, ZnSalenAg) on viability and proliferation of cultured human cancer cells.

Methods: The following cell lines were used as model systems: Human cervical carcinoma (cervical carcinoma), A549 (non-small cell lung cancer [NSCLC]), glioblastoma multiforme (8MGBA), and A431 (squamous cell carcinoma) and its multidrug-resistant (MDR) clones A431-MDR, A431-MRP, and A431-ABCG2 that express $m d r 1$, $m r p 1$, or $a b c g 2$ gene, respectively. The investigations were performed by thiazolyl blue tetrazolium bromide test, neutral red uptake cytotoxicity assay, crystal violet staining, hematoxylin and eosin staining, double staining with acridine orange, and propidium iodide in short-term experiments (12-72 h, with monolayer cell cultures) as well as colony-forming method in long-term experiments (25 days, with three dimensional cancer cell colonies).

Results: The results obtained revealed that ZnSalenAu and ZnSalenAg decreased significantly viability and proliferation of the treated cells in a time- and concentration-dependent manner being more active as compared to the free ligand $\mathrm{H}_{2} \mathrm{Salen}$.

Conclusion: The present study demonstrates for the $1^{\text {st }}$ time the ability of two heterometallic complexes ZnSalenAu and ZnSalenAg to decrease significantly viability and proliferation of cultured cell lines established from some of the most common and aggressive human cancers (NSCLC, carcinoma of uterine cancer, 8MGBA, and squamous cell carcinoma) as well as MDR cancer cells.

Keywords: Cytotoxic activity, Human cancer cell lines, $\mathrm{H}_{2}$ Salen, Schiff bases, $\mathrm{Zn}(\mathrm{II}) / \mathrm{Au}(\mathrm{I}), \mathrm{Zn}(\mathrm{II}) / \mathrm{Ag}(\mathrm{I})$ complexes.

(C) 2019 The Authors. Published by Innovare Academic Sciences Pvt Ltd. This is an open access article under the CC BY license (http://creativecommons. org/licenses/by/4. 0/) DOI: http://dx.doi.org/10.22159/ajpcr.2019.v12i1.28403

\section{INTRODUCTION}

Despite undoubted success in the early diagnosis, prevention, and treatment of cancer (at least some kinds), neoplastic diseases continue to be among the leading causes of morbidity and mortality worldwide with approximately 14.1 million new cases and 8.2 death cases in $2012[1,2]$. Chemotherapy is an important therapeutic strategy for cancer treatment, but its success is limited due to various obstacles including tumor heterogeneity, intrinsic or acquired (multi) drug resistance (MDR) of cancer cells, and severe side/toxic reactions. Hence, there is a constant need to develop effective new antitumor agents $[3,4]$.

The discovery of the antitumor properties of cisplatin, and later of carboplatin and oxaliplatin, encouraged efforts of scientists to search for other metals and metal compounds with pronounced antineoplastic activity and opened a new page in the development of medicinal chemistry and experimental oncopharmacology $[5,6]$.

Gold and silver have been used for medicinal purposes for thousands of years. The antimicrobial activity of silver has been known since ancient times, but there are also data about the anticancer activity of silver compounds [7-11].

Even in the $19^{\text {th }}$ century gold was still considered as "panacea." The modern age of gold in medicine began in the early $20^{\text {th }}$ century when Robert Koch discovered the antituberculosis effect of $\mathrm{K}\left[\mathrm{Au}(\mathrm{CN})_{2}\right]$ and
Jacques Forestier started to use thiolate gold salts for the treatment of rheumatoid arthritis $[5,12]$. Recent findings suggest that various $\mathrm{Au}(\mathrm{I})$ and $\mathrm{Au}(\mathrm{III})$ complexes can be potentially useful in cancer chemotherapy $[13,14]$.

Zinc is an essential element required for proper activity of $>300$ enzymes, 3000 proteins, and over 1000 transcription factors. This metal plays an important role in key biological processes including DNA replication and transcription, gene expression and genome integrity, normal functioning of the immune, and central nervous system [15-18]. Zinc deficiency has been associated to various pathological conditions such as inflammation, infections, and cancer $[17,19,20]$. Many research groups demonstrate encouraging the antineoplastic potential of zinc compounds [21-23]. As an essential element, zinc is expected to be less toxic than platinum, for example, gold and silver compounds also show relatively low toxicity $[24,25]$.

Schiff bases and their derivatives/metal complexes are also reported to express a wide range of biological activities, including antidiabetic and antitumor properties [26-30].

The aim of our study was to evaluate the influence of two heterometallic complexes ZnSalenAu, ZnSalenAg containing a Schiff base ligand $\left(\mathrm{H}_{2}\right.$ Salen) obtained from the condensation reaction between salicylaldehyde and ethylenediamine, on viability and proliferation of 
cultured human cancer cells. The X-ray structure, chemical and spectral characterization of the first complex $\left.C_{1}^{\infty}\left[\left\{\mathrm{Zn}_{3} \text { (Salen }\right)_{2}\right\}\left\{\mathrm{m}-\mathrm{Au}(\mathrm{CN})_{2}\right\}_{2}\right]$ denoted $\mathrm{ZnSalenAu}$ ) was reported in one of our previous paper [31]. For this reason, in this work, we report only the synthesis and physicochemical characterization of ZnSalenAg.

\section{MATERIALS AND METHODS}

\section{Materials}

Dulbecco's modified Eagle's medium (D-MEM) and fetal bovine serum (FBS) were purchased from Gibco-Invitrogen (UK). Dimethyl sulfoxide (DMSO), neutral red (NR), crystal violet (CV), and trypsin were obtained from AppliChem (Germany); purified agar (Difco) and thiazolyl blue tetrazolium bromide (MTT) were from Sigma-Aldrich Chemie $\mathrm{GmbH}$ (Germany). All sterile plasticware was from Orange Scientific (Belgium).

All starting materials for the synthesis of the complexes (salicylaldehyde, ethylenediamine, $\mathrm{Zn}\left(\mathrm{NO}_{3}\right)_{2} \bullet 4 \mathrm{H}_{2} \mathrm{O}, \quad \mathrm{K}\left[\mathrm{Au}(\mathrm{CN})_{2}\right]$, $\left.\mathrm{K}\left[\mathrm{Ag}(\mathrm{CN})_{2}\right]\right)$ were reagent grade and used without purification. The trinuclear $\mathrm{Zn}(\mathrm{II})$ precursors were synthesized by reacting the Schiff base $\left[\mathrm{H}_{2}\right.$ Salen - Scheme 1] obtained in situ by condensation of salicylaldehyde with ethylenediamine, with zinc(II) nitrate.

\section{Synthesis}

ZnSalenAg has been obtained following the same general synthetic procedure previously described for $\left.\left(_{1}^{\infty}\left[\left\{\mathrm{Zn}_{3}(\mathrm{Salen})_{2}\right\} \text { mm-Au(CN }\right)_{2}\right\}_{2}\right]$ (ZnSalenAu) [31], using $\mathrm{K}\left[\mathrm{Ag}(\mathrm{CN})_{2}\right]$ instead of $\mathrm{K}\left[\mathrm{Au}(\mathrm{CN})_{2}\right]$. ZnSalenAg was obtained as a yellow precipitate (yield ca. 70\%). Single crystals suitable for X-ray diffraction could not be obtained. Anal. Calcd for $\mathrm{C}_{36} \mathrm{H}_{28} \mathrm{Ag}_{2} \mathrm{~N}_{8} \mathrm{O}_{4} \mathrm{Zn}_{3}: 41.20 \% \mathrm{C}, 2.67 \% \mathrm{H}, 10.68 \% \mathrm{~N}$. Found: $41.98 \% \mathrm{C}$, $3.20 \% \mathrm{H}, 9.89 \% \mathrm{~N}$. infrared (IR) bands $\left(\mathrm{KBr}, \mathrm{cm}^{-1}\right): 3043 \mathrm{w}, 3010 \mathrm{w}$, 2898w, 2185vs (vCN), 1641vs, 1599m, 1541s, 1474s, 1447s, 1392m, 1339s, 1303s, 1192w, 1152m, 1128s, 1064m, 1051w, 1033m, 997w, 946m, 903w, 852m, 751s, 738m, 647w.

\section{Physical measurements}

IR spectra were recorded as $\mathrm{KBr}$ pellets on a JASCO Fourier-transform IR 4100 spectrophotometer from 4000 to $400 \mathrm{~cm}^{-t}$. Elemental analyzes of carbon, hydrogen, and nitrogen were carried out on a EuroEA elemental analyzer. Absorption spectra were recorded with a JASCO V-670 spectrophotometer. The photoluminescence measurements were carried out at room temperature using a JASCO FP 6500 spectrofluorometer.

\section{Cell cultures and cultivation}

The following human permanent cell lines were used as model systems in our study: Human cervical carcinoma (HeLa) (carcinoma of the uterine cervix), A549 (non-small cell lung cancer [NSCLC]), glioblastoma multiforme (8MGBA), and A431 (squamous cell carcinoma) and its

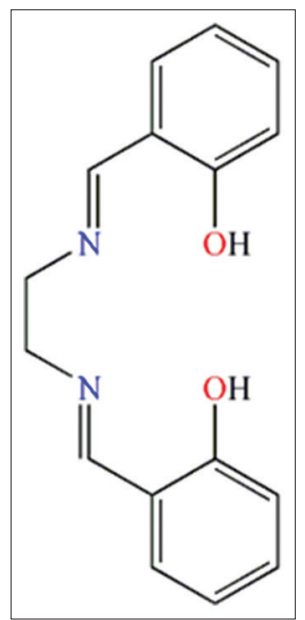

Scheme 1: $\mathrm{H}_{2}$ Salen structure
MDR clones A431-MDR, A431-MRP, and A431-ABCG2 that express $m d r 1, m r p 1$, or $a b c g 2$ gene, respectively. The freezing and thawing of the cells were performed according to the conventional methods $[32,33]$. The cells were grown as monolayer cultures in a D-MEM medium, supplemented with 5-10\% FBS, $100 \mathrm{U} / \mathrm{ml}$ penicillin and $100 \mu \mathrm{g} / \mathrm{ml}$ streptomycin. The cultures were maintained at $37^{\circ} \mathrm{C}$ in a humidified $\mathrm{CO}_{2}$ incubator (Thermo Scientific, HEPA Class 100). For routine passages, the cells were detached using a mixture of $0.05 \%$ trypsin $-0.02 \%$ ethylenediaminetetraacetic acid. The experiments were performed during the exponential phase of cell growth.

\section{Cytotoxicity assays}

The cells were seeded in 96-well flat-bottomed microplates at a concentration of $1 \times 104$ cells/well. After the cells were grown for $24 \mathrm{~h}$ to a subconfluent state $(\sim 60-70 \%)$, the culture medium was removed and changed by media modified with different concentrations $(0.1,0.5$, 1,5 , and $10 \mu \mathrm{g} / \mathrm{ml}$ ) of the compounds tested. Each concentration was applied into 4-8 wells. Samples of cells grown in non-modified medium served as controls. After 12, 18, 24, 48, and $72 \mathrm{~h}$ of incubation, the effect of the compounds on cell viability and proliferation was examined by MTT test, NR uptake cytotoxicity assay, and CV staining.

The MTT colorimetric assay of cell survival was performed as described by Mosmann [34]. The method consisted of $3 \mathrm{~h}$ incubation with MTT solution (5 mg MTT in $10 \mathrm{~mL}$ D-MEM) at $37^{\circ} \mathrm{C}$ under $5 \%$ carbon dioxide and $95 \%$ air, followed by extraction with a mixture of absolute ethanol and DMSO $(1: 1, \mathrm{vol} / \mathrm{vol})$ to dissolve the blue formazan.

The NR assay was based on the method of Borenfreund and Puerner [35]. To each well-containing corresponding cells a medium consisting of NR ( $50 \mu \mathrm{g} / \mathrm{mL}, 0.1 \mathrm{~mL})$ was added. The plate was placed in the $\mathrm{CO}_{2}$ incubator for $3 \mathrm{~h}$ for the uptake of vital dye. Thereafter, the medium with NR was removed, and the cells were washed with phosphate saline buffer (PBS, $0.2 \mathrm{~mL} /$ well), followed by the addition of $0.1 \mathrm{~mL} 1 \%$ acetic acid solution containing $50 \%$ ethanol to extract the dye from the cells.

The CV assay was based on the method of Saotome et al. [36]. After each well was washed with PBS, the cells were fixed and stained with $0.4 \% \mathrm{CV}$ solution in methanol for $30 \mathrm{~min}$. Optical density was measured at $540 \mathrm{~nm}$ using an automatic microplate reader (TECAN, Sunrise $^{T M}$, Austria). Relative cell viability, expressed as a percentage of the untreated control (100\% viability), was calculated for each concentration. Concentration-response curves were prepared and the effective cytotoxic concentration (CC) of the compounds $\mathrm{CC}_{50}(\mu \mathrm{M})$ and $\mathrm{CC}_{90}(\mu \mathrm{M})$ causing, respectively, $50 \%$ and $90 \%$ reduction of cell viability was estimated from these curves. All data points represent an average of three independent assays.

\section{Hematoxylin and eosin (HE) staining}

The cells were grown on coverslips $\left(3.0-3.5 \times 10^{5}\right.$ cells/well) in 6-well plates in the presence of the compounds tested. Non-treated cells served as controls. After 24,48 , and $72 \mathrm{~h}$ of incubation, the coverslips were removed, washed with PBS, fixed in methanol $(2 \times 15 \mathrm{~min})$ and stained with HE. Dehydration was performed in increasing concentrations of alcohols (70\%, 80\%, 96\%, and 100\% ethyl alcohol), followed by xylene treatment $(2 \times 15 \mathrm{~min})$ and mounting in cedar oil. The microscopic preparations were examined under the light microscope (Leika DM 500B, Wetzlar, Germany).

\section{Double staining with acridine orange (AO) and propidium iodide} (PI)

The ability of compounds to induce cytopathological changes was assessed using double staining with $\mathrm{AO}$ and PI according to the standard procedures [37]. The cells were grown on coverslips and treated as it was described in the previous paragraph. After 24,48 , and $72 \mathrm{~h}$ of incubation, the coverslips were removed and washed with PBS for $2 \mathrm{~min}$. Equal volumes of fluorescent dyes containing AO $(10 \mu \mathrm{g} / \mathrm{mL}$ in PBS) and PI (10 $\mu \mathrm{g} / \mathrm{mL}$ in bidistilled water) were added to the cells. 
Fresh stained cells were placed on a glass slide and examined under a fluorescence microscope (Leika DM 500B, Wetzlar, Germany) within $30 \mathrm{~min}$ before the fluorescent color started to fade.

\section{Colony forming method}

Tumor cells $\left(10^{3}\right.$ cells/well $)$ suspended in $0.45 \%$ purified agar in D-MEM medium containing different concentrations of the compounds examined (ranging from 0.5 to $25 \mu \mathrm{g} / \mathrm{mL}$ ) were layered in 24 well microplates. The presence/absence of colonies was registered using an inverted microscope (Carl Zeiss, Germany) during the period of 25 days. Colony inhibitory concentration (CIC, $\mu \mathrm{M}$ ) at which the compounds tested inhibit completely the ability of tumor cells to grow in a semisolid medium was determined.

\section{Statistical analysis}

The data are presented as mean \pm standard error of the mean. Statistical differences between control and treated groups were assessed using one-way analysis of variance followed by Dunnett post hoc test and Origin $6.1^{\mathrm{TM}}$.

\section{RESULTS AND DISCUSSION}

\section{Physical and chemical properties}

Due to the impossibility of obtaining monocrystals suitable for $\mathrm{X}$-ray measurements, we tried to establish the molecular formula of ZnSalenAg by correlating the chemical analysis with spectral data.

The IR spectrum of ZnSalenAg (Fig. 1) contains some main bands which certify the formation of the complex: $3010 \mathrm{~cm}^{-\mathrm{h}}\left(\mathrm{v}_{\text {asim }} \mathrm{C}-\mathrm{H}\right), 2898$ $\mathrm{cm}^{-\mathrm{H}}\left(v_{\text {sim }} \mathrm{C}-\mathrm{H}\right), 2185 \mathrm{~cm}^{-\mathrm{H}}(\mathrm{vCN}$ bridge $), 1641 \mathrm{~cm}^{-\mathrm{b}}$ ( $\mathrm{vC}=\mathrm{N}$ azomethine), $1541,1474,1447 \mathrm{~cm}^{-\mathrm{c}}(\mathrm{vC}=\mathrm{C})$.

The other small bands are characteristic to the Schiff base ligand. Comparing the spectrum of $\mathrm{ZnSalenAg}$ with that of the free ligand, some slight displacements of the bands were observed, confirming its involvement in complexation. Another important information regarding the structure of the complex is given by the absence of the bands corresponding to nitrate anion that confirm its replacement by $\left[\mathrm{Ag}(\mathrm{CN})_{2}\right]^{-}$units.

The similarity between the data obtained for ZnSalenAg and those of $\mathrm{ZnSalenAu} \mathrm{[31]} \mathrm{encouraged} \mathrm{us} \mathrm{to} \mathrm{propose} \mathrm{a} \mathrm{similar} \mathrm{molecular} \mathrm{formula}$ for ZnSalenAg: ${ }_{1}^{\infty}\left[\left\{\mathrm{Zn}_{3}(\text { Salen })_{2}\right\}\left\{\mu-\mathrm{Ag}(\mathrm{CN})_{2}\right\}_{2}\right]$.
The electronic spectrum of ZnSalenAg shows bands located in the 200-500 nm region (Fig. 2). These bands are must probably due to a superposition of $\pi-\pi^{*}$ transitions of the organic ligand that appears at higher energies and strong MLCT $\left(d-\pi^{*}\right)$ transitions characteristic for dicyanoargentate polymers.

It is known that silver(I) and gold(I) complexes have attracted attention in the field of the photophysics of metal complexes. The structures constructed through metallophilic interactions are known to be potentially luminescent materials [38]. For these reasons, the luminescent properties of Schiff-base ligand and ZnSalenAg (in solid state), at room temperature, have been investigated (Fig. 3). For $\mathrm{H}_{2}$ Salen a green emission was observed with the maximum at $504 \mathrm{~nm}$ by excitation with $370 \mathrm{~nm}$.

The emission spectrum of ZnSalenAg presented in Fig. 3 exhibits luminescence with a peak maximum at $\lambda_{\text {em }}=447 \mathrm{~nm}$, slightly shifted compared with that observed for ZnSalenAu (464 nm) [31]. Compared with the free ligand, emission of $\mathrm{ZnSalenAg}$ is slightly shifted to lower wavenumber as a result of coordination of zinc(II) centers to the ligand, and the luminescence is most probably due to intraligand ${ }^{1}\left(\pi^{*}-\pi\right)$ fluorescence.

\section{Cytotoxic activity}

\section{Short-term experiments}

The investigations were performed in two steps: (1) The influence of the compounds investigated on viability and proliferation of cancer (HeLa, A549, 8MGBA, A431, and its clones) cells used as model systems in our study was evaluated initially by MTT test - the gold standard for cytotoxicity assays. The "concentration - response" curves were prepared (examples of such curves are presented in Figs. 4-7) and effective concentrations $\mathrm{CC}_{50}$ and $\mathrm{CC}_{90}$ that reduce cell viability by $50 \%$ and $90 \%$, respectively, as compared to the control, were calculated from these curves where possible (Tables 1-3).

The results obtained reveal that ZnSalenAu and ZnSalenAg decrease significantly viability and/or proliferation of the treated cells in a time- and concentration-dependent manner being more active cytotoxic agents as compared to $\mathrm{H}_{2} \mathrm{Salen}$. For instance, $\mathrm{CC}_{50}$ of $\mathrm{ZnSalenAu}$ and ZnSalenAg (determined by MTT, $72 \mathrm{~h}$ ) were found to be $<6.5 \mu \mathrm{M}$ and $<7.5 \mu \mathrm{M}$, respectively. The experimental design was extended using additional methods with different molecular/cellular targets and mechanisms of action * NR uptake cytotoxicity assay and CV staining

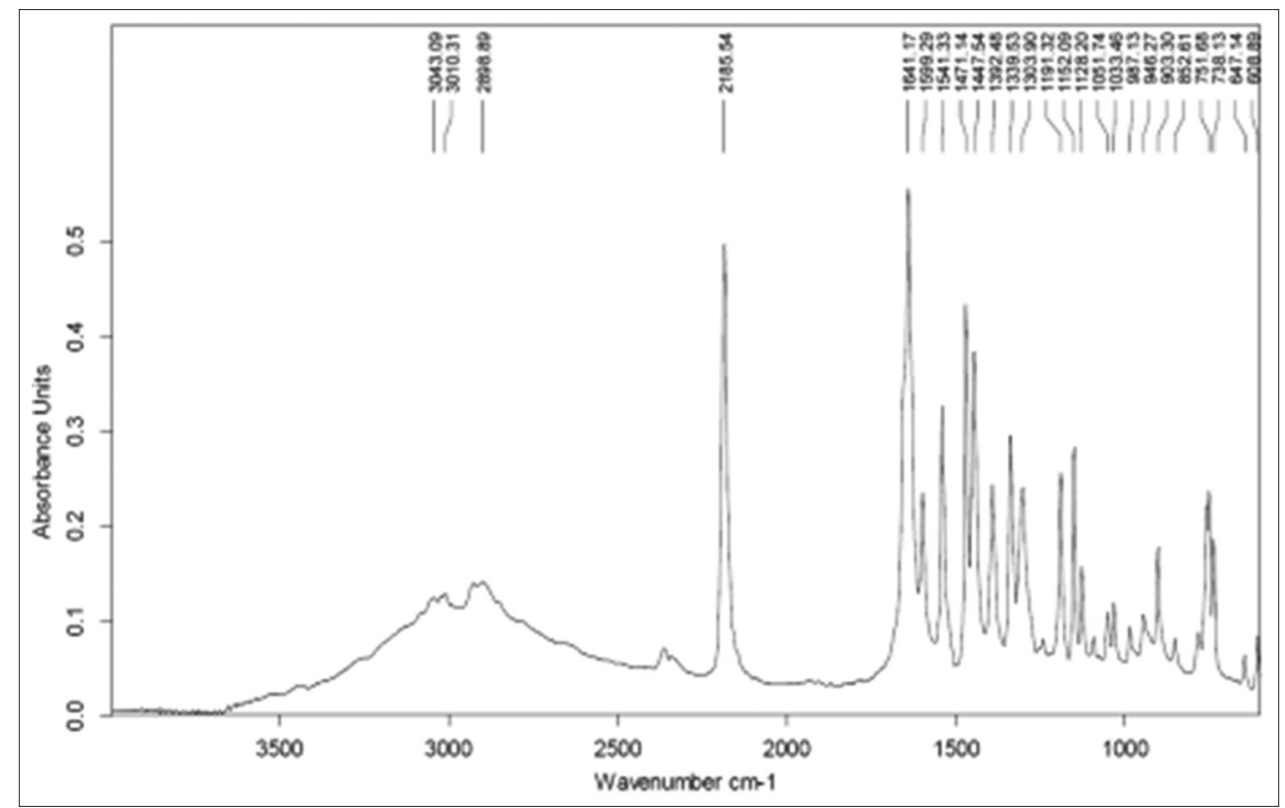

Fig. 1: Infrared spectrum of ZnSalenAg 
Table 1: $\mathrm{CC}_{50} \mu \mathrm{M}$ and $\mathrm{CC}_{90} \mu \mathrm{M}$ of ZnSalenAu and ZnSalenAg for HeLa cell line

\begin{tabular}{|c|c|c|c|c|}
\hline Treatment period (h) & Method & H2Salen & ZnSalenAu & ZnSalenAg \\
\hline 12 & MTT & n.d. & $0.52^{*}(3.67)^{* *}$ & $3.13(4.70)$ \\
\hline 18 & & n.d. & $0.46(2.64)$ & $2.99(4.47)$ \\
\hline 24 & & n.d. & 0.41 (n.d.) & $2.89(4.46)$ \\
\hline 48 & & n.d. & $0.23(0.41)$ & $2.59(4.33)$ \\
\hline \multirow[t]{3}{*}{72} & MTT & n.d. & $0.28(0.63)$ & $1.76(4.17)$ \\
\hline & $\mathrm{NR}$ & n.d. & $0.80(3.40)$ & $2.04(4.18)$ \\
\hline & $\mathrm{CV}$ & n.d. & 2.94 (n.d.) & 2.83 (n.d.) \\
\hline
\end{tabular}

${ }^{*} \mathrm{CC}_{50} \mu \mathrm{M},{ }^{* *} \mathrm{CC}_{90} \mu \mathrm{M}, \mathrm{MTT}$ : Thiazolyl blue tetrazolium bromide test, NR: Neutral red uptake cytotoxicity assay, CV: Crystal violet staining, n.d. - CC ${ }_{50}:$ Respectively,

$\mathrm{CC}_{90}$ was not determined because at all examined concentrations $(0.1-10 \mu \mathrm{g} / \mathrm{ml})$ the cell viability was $>50 \%$, respectively, $>10 \%$. CC: Cytotoxic concentration

Table 2: $\mathrm{CC}_{50} \mu \mathrm{M}$ and $\mathrm{CC}_{90} \mu \mathrm{M}$ of ZnSalenAu and ZnSalenAg for human A549 and 8MGBA cell lines

\begin{tabular}{lllll}
\hline A 549 cell line & \multicolumn{3}{l}{} \\
\hline Treatment period & Method & H2Salen & ZnSalenAu & ZnSalenAg \\
\hline 48 & MTT & n.d. & $2.50^{*}(3.91)^{* *}$ & $2.54(7.60)$ \\
72 & & n.d. & $6.46(8.90)$ & $7.32(9.54)$ \\
\hline 8MGBA cell line & & & & \\
\hline 24 & MTT & n.d. & $1.34(8.15)$ & $2.74(4.49)$ \\
48 & & n.d. & $0.45(2.89)$ & $2.75(4.35)$ \\
72 & & n.d. & $0.65(3.34)$ & $3.19(4.48)$ \\
\hline
\end{tabular}

${ }^{*} \mathrm{CC}_{50} \mu \mathrm{M},{ }^{* *} \mathrm{CC}_{90} \mu \mathrm{M}, \mathrm{MTT}$ : Thiazolyl blue tetrazolium bromide test, n.d. - $\mathrm{CC}_{50}$, respectively, $\mathrm{CC}_{90}$, was not determined because at all examined concentrations $(0.1-10 \mu \mathrm{g} / \mathrm{ml})$ the cell viability was $>50 \%$, respectively, $>10 \%$. CC: Cytotoxic concentration, 8MGBA: Glioblastoma multiforme

Table 3: $\mathrm{CC}_{50} \mu \mathrm{M}$ and $\mathrm{CC}_{90} \mu \mathrm{M}$ of $\mathrm{ZnSalenAu}$ and $\mathrm{ZnSalenAg}$ against human squamous cell carcinoma cell line A431 and its multidrug-resistant clones

\begin{tabular}{|c|c|c|}
\hline \multirow[t]{2}{*}{ Cell line } & ZnSalenAu & \multirow[t]{2}{*}{ ZnSalenAg } \\
\hline & MTT, 72 h & \\
\hline A431 & $0.98^{*}(3.42)^{* *}$ & $3.10(4.38)$ \\
\hline A431-MDR1 & $2.46(6.28)$ & $2.06(4.24)$ \\
\hline A431-MRP1 & $2.67(8.15)$ & $2.28(4.46)$ \\
\hline A431-ABCG2 & $2.16(3.60)$ & $3.82(4.58)$ \\
\hline
\end{tabular}

${ }^{*} \mathrm{CC}_{50} \mu \mathrm{M} ;{ }^{* *} \mathrm{CC}_{90} \mu \mathrm{M}$, MTT: Thiazolyl blue tetrazolium bromide test,

CC: Cytotoxic concentration, 8MGBA: Glioblastoma multiforme. CC: Cytotoxic concentration, MDR: Multidrug-resistant

on HeLa cervical carcinoma cell line, due to its high sensitivity to the cytotoxic activity of the examined compounds and wide application as a model system in laboratory practice.

The $\mathrm{CC}_{50}$ and $\mathrm{CC}_{90}$ values for HeLa cells measured by MTT, NR, and CV assays are presented in Table 1 . The cytopathological changes (such as reduced cell number, vacuolization of cytoplasm, cell picnosis, and apoptotic bodies) in HeLa cells cultured in the presence of $\mathrm{ZnSalenAu}$ and $\mathrm{ZnSalenAg}$ are visualized by $\mathrm{HE}$ staining as well as double staining with AO and PI (Fig. 8).

\section{Long-term experiments}

The MTT, NR, CV, HE, and AO/PI assays demonstrate the "quick" (12-72 h) effect of the compounds tested on monolayer (two dimensional [2D]) cell cultures whereas the colony-forming method reveals their long-term ability to suppress the three dimensional (3D) growth of cancer cells. 3D cell cultures have been considered to be more physiologically relevant and predictive model systems than 2D cell cultures. Various differences between 2D and 3D experimental cell models have been reported including response to therapeutic agents, demonstrating the advantages of 3D cell culturing $[39,40]$. It has been found in our investigations that both metal complexes completely inhibit 3D growth of HeLa cells in a semi-solid medium administered

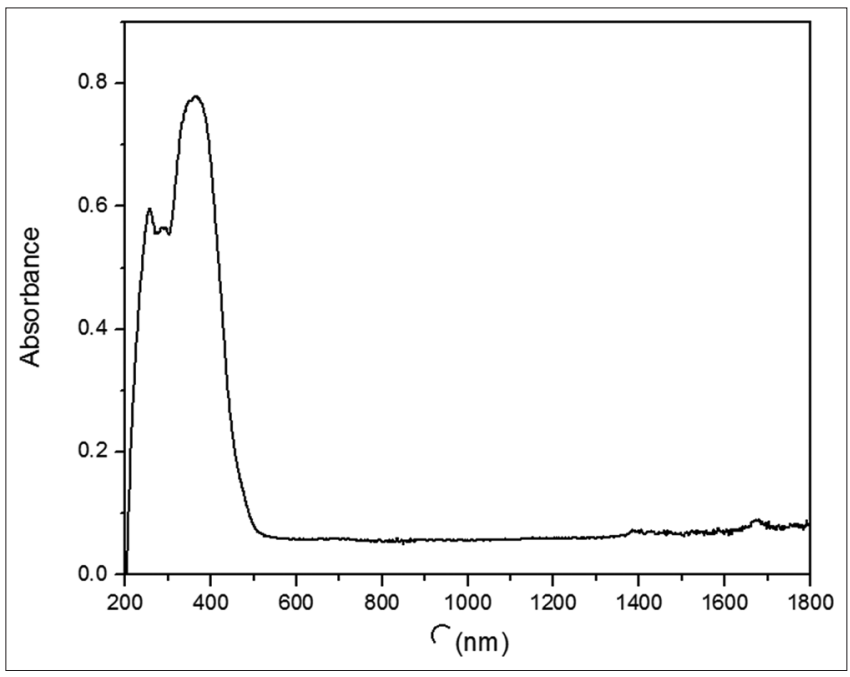

Fig. 2: The UV-visible spectrum of ZnSalenAg

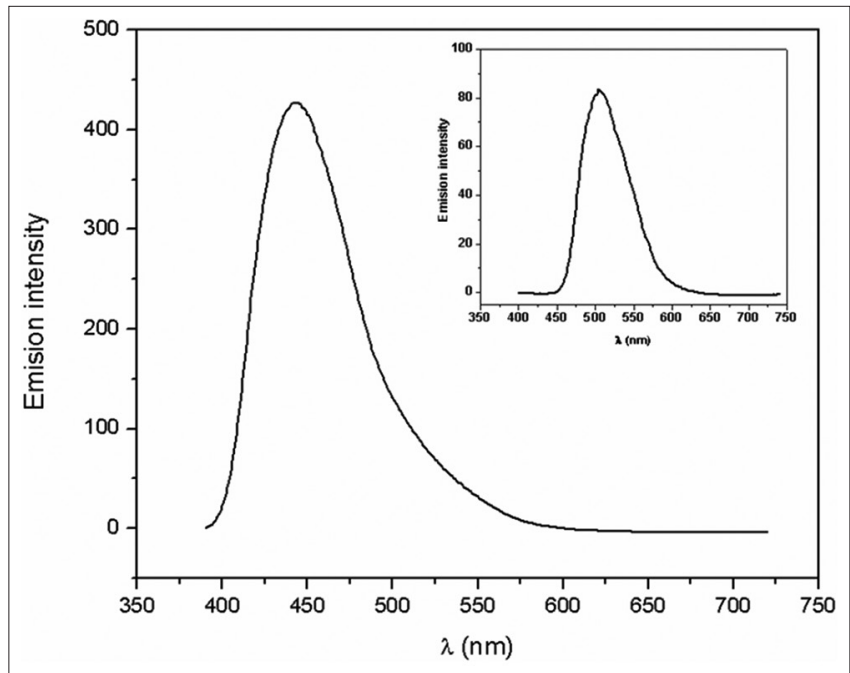

Fig. 3: Solid-state emission spectrum of ZnSalenAg at room temperature $\left(\lambda_{\mathrm{exc}}=370 \mathrm{~nm}\right)$ (inset - emission spectrum of $\mathrm{H}_{2}$ Salen)

at concentrations $\geq 0.41 \mu \mathrm{M}(0.5 \mu \mathrm{g} / \mathrm{ml}, \mathrm{ZnSalenAu})$ and $\geq 0.47 \mu \mathrm{M}$ (0.5 $\mu \mathrm{g} / \mathrm{ml}$, ZnSalenAg). Applied independently, $\mathrm{H}_{2}$ Salen does not inhibit 3D colony-forming ability of HeLa cells.

In this study, we report for the $1^{\text {st }}$ time the ability of ZnSalenAu and ZnSalenAg to inhibit the 2D- and 3D-growth of cultured human cancer cells. It's worth mentioning that our model systems used in our experiments provoke interest due to the following reasons: (i) Lung cancer is among the most frequent and deadly neoplastic diseases. NSCLC is the most common form of lung cancer representing about $85 \%$ of all cases. In $85-90 \%$ of the 


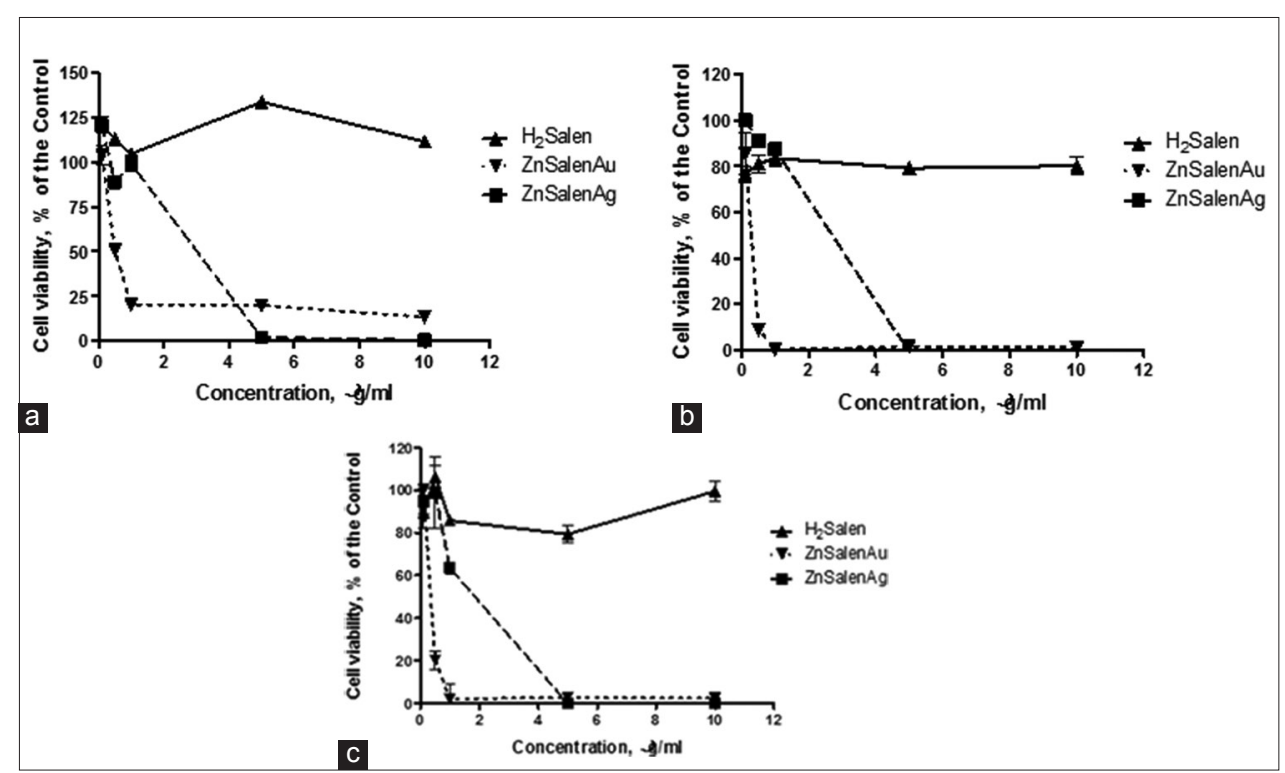

Fig. 4: Concentration-response curves of $\mathrm{ZnSalenAu}, \mathrm{ZnSalenAg}$ and their ligand $\mathrm{H}_{2}$ Salen for human cervical carcinoma cells evaluated by thiazolyl blue tetrazolium bromide test after $24 \mathrm{~h} \mathrm{(a),} 48 \mathrm{~h}(\mathrm{~b})$, and $72 \mathrm{~h}(\mathrm{c})$ treatment period

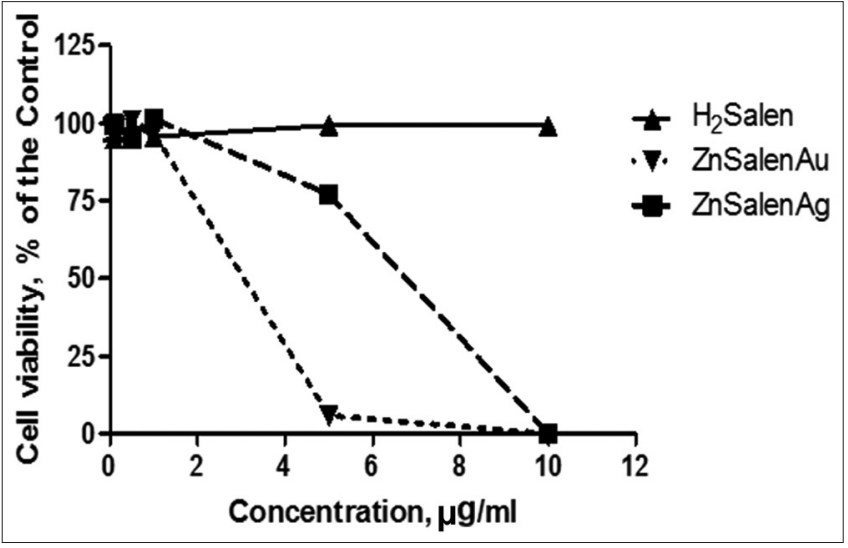

Fig. 5: Concentration-response curves of ZnSalenAu, ZnSalenAg and their ligand $\mathrm{H}_{2}$ Salen for human non-small cell lung cancer (A549) cells evaluated by thiazolyl blue tetrazolium bromide test after $48 \mathrm{~h}$ treatment period

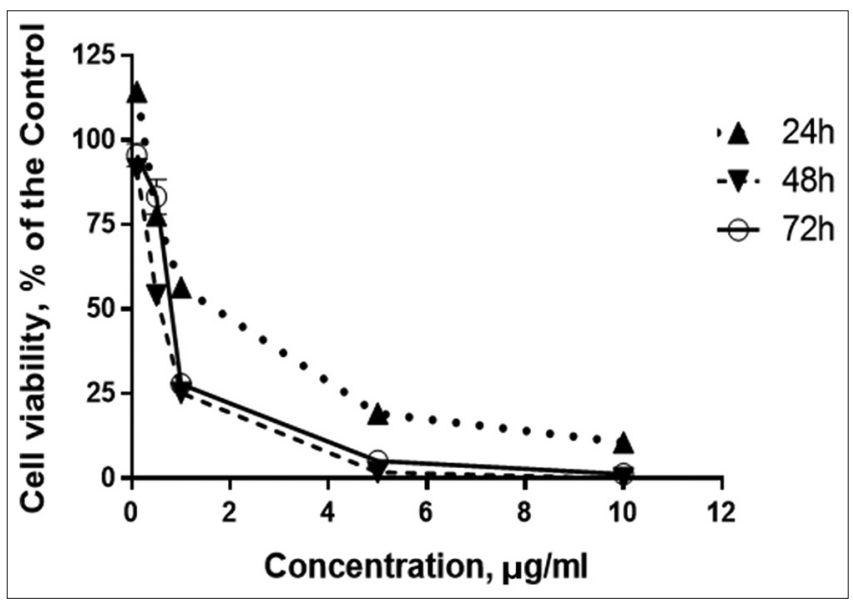

Fig. 6: Concentration-response curves of $\mathrm{ZnSalenAu}$, for human glioblastoma multiforme cells evaluated by thiazolyl blue tetrazolium bromide test after $24 \mathrm{~h}, 48 \mathrm{~h}$, and $72 \mathrm{~h}$ treatment period

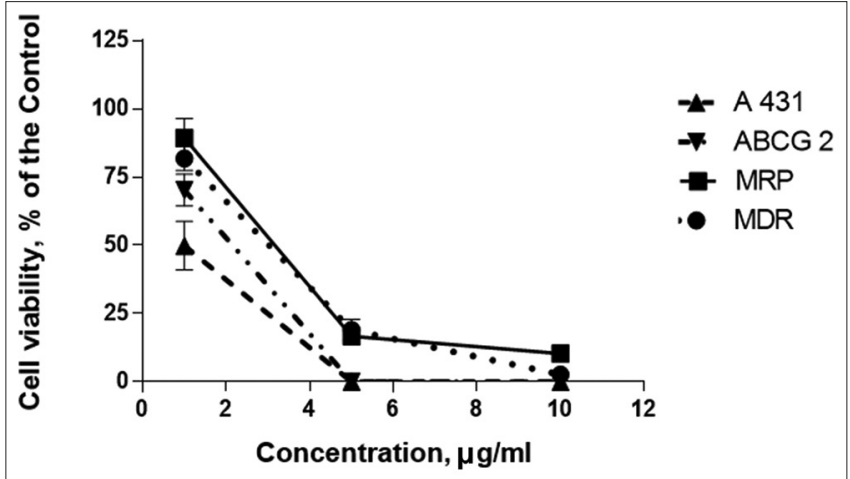

Fig. 7: Concentration-response curves of ZnSalenAu for human squamous cell carcinoma cells (A431 parental cell line and its drug-resistant clones) evaluated by thiazolyl blue tetrazolium bromide test after $72 \mathrm{~h}$ treatment period

cases, the disease is diagnosed later (IIIB and IV stages) when the patients are inoperable, and the main treatment is conservative chemotherapy and/or radiotherapy [41]; (ii) 8MGBA is a highly aggressive cancer. The survival rate of people affected by this disease has remained virtually unchanged over the past few decades and is only 6-12-15 months after the diagnosis despite advances in surgical approaches, radiation, and chemotherapy, 5-year survival remains $<3 \%$ [42,43]; (iii) drug resistance is the main obstacle preventing successful chemotherapy of cancer. The so-called ATP-binding cassette proteins transporters (such as the products of $m d r 1, m r p 1$, and $a b c g 2$ genes) are key players in MDR phenomenon [44,45]; (iv) carcinoma of the uterine cervix is among the most frequent malignancies in women $[46,47]$. HeLa is the oldest and the most widely used cell culture model in biomedical research $[48,49]$.

Although both metal complexes are active, the $\mathrm{CC}_{50}$ and $\mathrm{CC}_{90}$ of $\mathrm{ZnSalenAu}$ are lower than those of ZnSalenAg. Our preliminary investigations with $\mathrm{Ru}(\mathrm{III})$ complexes with $\mathrm{H}_{2}$ Salen reveal that they possess significantly lower cytotoxic activity for HeLa cells as compared to $\mathrm{Zn}(\mathrm{II}) / \mathrm{Au}(\mathrm{I})$ and $\mathrm{Zn}(\mathrm{II}) / \mathrm{Ag}(\mathrm{I})$ complexes with the same ligand (not published data).

\section{CONCLUSION}

In this study, we report for the $1^{\text {st }}$ time the ability of two heterometallic complexes ZnSalenAu and ZnSalenAg containing a Schiff base 

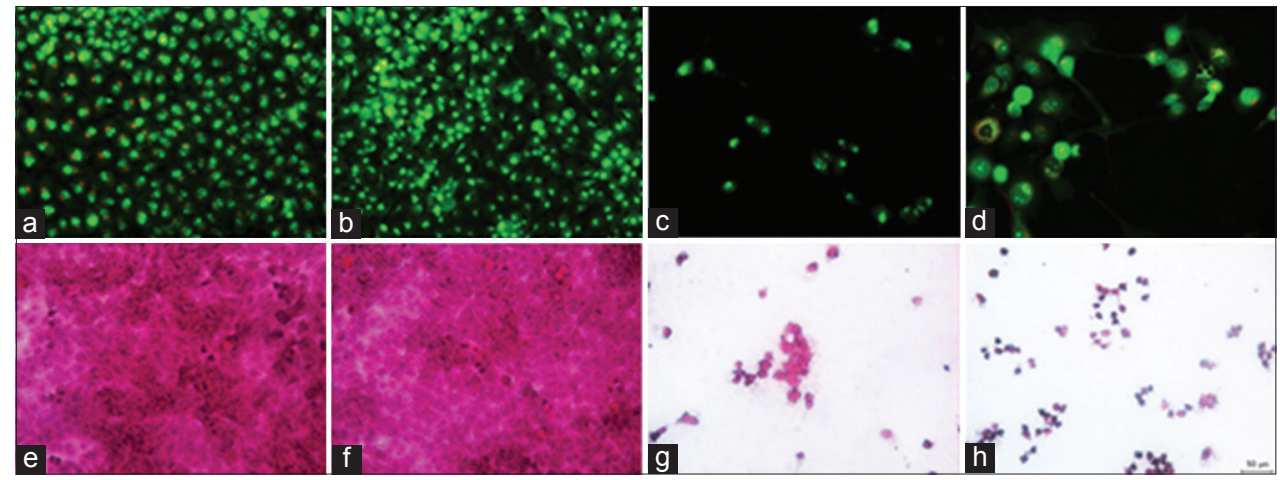

Fig. 8. (a) Non-treated HeLa cells - Control, (b-d) HeLa cells after $72 \mathrm{~h}$ of treatment with $10 \mu \mathrm{g} / \mathrm{ml} \mathrm{H} \mathrm{H}_{2}$ Salen (b), $0.5 \mu \mathrm{g} / \mathrm{ml} \mathrm{ZnSalenAu}$ (c), $5 \mu \mathrm{g} / \mathrm{ml} \mathrm{ZnSalenAg} \mathrm{(d} \mathrm{and} \mathrm{e),} \mathrm{untreated} \mathrm{HeLa} \mathrm{cells} \mathrm{-} \mathrm{Control,} \mathrm{(f} \mathrm{and} \mathrm{g)} \mathrm{HeLa} \mathrm{cells} \mathrm{after} 72 \mathrm{~h}$ treatment with $10 \mu \mathrm{g} / \mathrm{ml} \mathrm{H} \mathrm{H}_{2} \mathrm{Salen}$ (f), 0.4 $\mu \mathrm{g} / \mathrm{ml} \mathrm{ZnSalenAu}(\mathrm{g}), 2.5 \mu \mathrm{g} / \mathrm{ml} \mathrm{ZnSalenAg}(\mathrm{h})$, double staining with propidium iodide and acridine orange (a-d), double staining with hematoxylin and eosin (e-h), Bar=50 $\mu \mathrm{m}$

ligand $\left(\mathrm{H}_{2}\right.$ Salen) obtained from the condensation reaction between salicylaldehyde and ethylenediamine, to decrease significantly viability and proliferation of cultured cell lines established from some of the most common and aggressive human cancers (NSCLC, carcinoma of the uterine cancer, 8MGBA, and squamous cell carcinoma) as well as MDR cancer cells. The cytotoxic activity of the compounds investigated was prove by in short-term and long-term experiments using 2D and 3D cell cultures and methods with different molecular/cellular targets and mechanisms of action. Additional investigations are underway to clarify better the antineoplastic potential of ZnSalenAu and ZnSalenAg.

\section{ACKNOWLEDGMENT}

Supported by National Fund "Scientific Research," Ministry of Education and Science, Bulgaria (Grant № DFNI Б-02-30/December 12, 2014) and a bilateral project between Bulgarian Academy of Sciences and Romanian Academy.

\section{AUTHORS' CONTRIBUTIONS}

Gabriela Marinescu specifically contributed for the chemical part and Radostina Alexandrova for the biological part. All the authors contributed equally in publishing this manuscript.

\section{CONFLICTS OF INTEREST}

The author(s) declare(s) that there are no conflicts of interest regarding the publication of this article.

\section{REFERENCES}

1. Ferlay J, Steliarova-Foucher E, Lortet-Tieulent J, Rosso S, Coebergh JW, Comber $\mathrm{H}$, et al. Cancer incidence and mortality patterns in Europe: Estimates for 40 countries in 2012. Eur J Cancer 2012;49:1374-403.

2. Torre LA, Bray F, Siegel RL, Ferlay J, Lortet-Tieulent J, Jemal A, et al. Global cancer statistics, 2012. CA Cancer J Clin 2015;65:87-108,

3. Ali R, Mirza Z, Ashraf GM, Kamal MA, Ansari SA, Damanhouri GA, et al. New anticancer agents: Recent developments in tumor therapy. Anticancer Res 2012;32:2999-3005.

4. Gupta M, Dahiya J, Marwaha R, Dureja H. Therapies in cancer treatment: An overview. Int J Pharm Pharm Sci 2015;7:1-9.

5. Desoize B. Metals and metal compounds in cancer treatment. Anticancer Res 2004:24:1529-44.

6. Ndagi U, Mhlongo N, Soliman ME. Metal complexes in cancer therapy-an update from drug design perspective. Drug Des Devel Ther 2017:11:599-616.

7. Banti CN, Hadjikakou SK. Anti-proliferative and anti-tumor activity of silver(I) compounds. Metallomics 2013;5:569-96.

8. Liu JJ, Galettis P, Farr A, Maharaj L, Samarasinha H, McGechan AC, et al. In vitro antitumour and hepatotoxicity profiles of au(I) and ag(I) bidentate pyridyl phosphine complexes and relationships to cellular uptake. J Inorg Biochem 2008;102:303-10.

9. Thati B, Noble A, Creaven BS, Walsh M, McCann M, Kavanagh K, et al. A study of the role of apoptotic cell death and cell cycle events mediating the mechanism of action of 6-hydroxycoumarin3-carboxylatosilver in human malignant hepatic cells. Cancer Lett 2007;250:128-39.

10. Thati B, Noble A, Creaven BS, Walsh M, McCann M, Kavanagh K, et al. In vitro anti-tumour and cyto-selective effects of coumarin-3carboxylic acid and three of its hydroxylated derivatives, along with their silver-based complexes, using human epithelial carcinoma cell lines. Cancer Lett 2007;248:321-31.

11. Zhu HL, Zhang XM, Liu XY. Clear Ag-Ag bonds in three sil-ver(I) carboxylate complexes with high cytotoxicity properties. Inorg Chem Commun 2003;6:1113-6.

12. Messori L, Marcon G. Gold complexes in the treatment of rheumatoid arthritis. Met Ions Biol Syst 2004;41:279-304.

13. Kostova I. Gold coordination complexes as anticancer agents. Anticancer Agents Med Chem 2006;6:19-32.

14. Messori L, Marcon G. Gold complexes as antitumor agents. Met Ions Biol Syst 2004:42:385-424.

15. Khalid N, Ahmed A, Bhatti MS, Randhawa MA, Ahmad A, Rafaqat R, et al. A question mark on zinc deficiency in 185 million people in Pakistan-possible way out. Crit Rev Food Sci Nutr 2014;54:1222-40.

16. Maret W. Zinc and human disease. Met Ions Life Sci 2013;13:389-414.

17. Prasad AS. Discovery of human zinc deficiency: Its impact on human health and disease. Adv Nutr 2013;4:176-90.

18. Prasad AS. Zinc: Role in immunity, oxidative stress and chronic inflammation. Curr Opin Clin Nutr Metab Care 2009;12:646-52.

19. Costello LC, Franklin RB. Zinc is decreased in prostate cancer: An established relationship of prostate cancer! J Biol Inorg Chem 2011;16:3-8

20. Prasad AS, Beck FW, Snell DC, Kucuk O. Zinc in cancer prevention. Nutr Cancer 2009;61:879-87.

21. Adhikari A, Kumari N, Adhikari M, Kumar N, Tiwari AK, Shukla A, etal. Zinc complex of tryptophan appended 1,4,7,10-tetraazacyclododecane as potential anticancer agent: Synthesis and evaluation. Bioorg Med Chem 2017;25:3483-90.

22. Alexandrova R, Rashkova G, Salkova D, Sainova I. Something more about zinc. Exp Pathol Parasitol 2002;5:17-24.

23. Milosavljevic V, Haddad Y, Merlos Rodrigo MA, Moulick A, Polanska H, Hynek D, et al. The zinc-schiff base-novicidin complex as a potential prostate cancer therapy. PLoS One 2016;11:e0163983.

24. Drake PL, Hazelwood KJ. Exposure-related health effects of silver and silver compounds: A review. Ann Occup Hyg 2005;49:575-85.

25. Jones G, Brooks PM. Injectable gold compounds: An overview. Br J Rheumatol 1997;24:633-8.

26. Al Zoubi W. Biological activities of Schiff bases and their complexes: A review of recent works. Int J Org Chem 2013;3:73-95.

27. Arulmurugan S, Kavitha PH, Venkatraman BR. Biological activities of Schiff base and its complexes: A review. Rasayan J Chem 2010;3:385-410.

28. Gaikwad VK, Yadav UM. Metal complexes of Schiff bases. Sch Res J Interdiscip Stud 2016;3:2225-34.

29. Qin W, Long S, Panunzio M, Biondi S. Schiff bases: A short survey on an evergreen chemistry tool. Molecules 2013;18:12264-89.

30. Maanvizhi S, Boppana T, Krishnan C, Arumugam G. Metal complexes in the management of diabetes mellitus: A new therapeutic strategy. Int 
J Pharm Pharm Sci 2014;6:40-4.

31. Marinescu G, Madalan AM, Andruh M. New heterometallic coordination polymers based on zinc(II) complexes with Schiff-base ligands and dicyanometallates: Synthesis, crystal structures, and luminescent properties. J Coord Chem 2015;68:479.

32. Alexandrov I, Toshkova R, Alexandrov M, Dimitrov T, Sotirov N. Two tumor-associated membrane antigens defined by monoclonal antibodies in a transplantable sarcoma induced by Rous sarcoma virus in rat. Neoplasma 1996;43:275-82.

33. Alexandrov I, Toshkova R, Alexandrov M, Dimitrov T, Sotirov N. Tumor-associated antigens on rat sarcoma cells identified by monoclonal antibodies. Exp Oncol 1996;18:43-50.

34. Mosmann T. Rapid colorimetric assay for cellular growth and survival: Application to proliferation and cytotoxicity assays. J Immunol Methods 1983;65:55-63.

35. Borenfreund E, Puerner JA. Toxicity determined in vitro by morphological alterations and neutral red absorption. Toxicol Lett 1985;24:119-24.

36. Saotome K, Morita H, Umeda M. Cytotoxicity test with simplified crystal violet staining method using microtitre plates and its application to injection drugs. Toxicol In Vitro 1989;3:317-21.

37. Abdel Wahab SI, Abdul AB, Alzubairi AS, Mohamed Elhassan M, Mohan S. In vitro ultramorphological assessment of apoptosis induced by zerumbone on (HeLa). J Biomed Biotechnol 2009;2009:769568.

38. Liu CS, Chen PQ, Chang Z, Wang JJ, Yan LF, Sun HW, et al. A photoluminescent hexanuclear silver(I) complex exhibiting $\mathrm{C}-\mathrm{H}$ Ag close interactions. Inorg Chem Commun 2008;11:159-63.

39. Levinger I, Ventura Y, Vago R. Life is three dimensional-as in vitro cancer cultures should be. Adv Cancer Res 2014;121:383-414

40. Ravi M, Paramesh V, Kaviya SR, Anuradha E, Solomon FD. 3D cell culture systems: Advantages and applications. J Cell Physiol 2015;230:16-26.

41. Liu J, Ma S. Recent development in the discovery of anaplastic lymphoma kinase (ALK) inhibitors for non-small cell lung cancer. Curr Med Chem 2017;24:590-613.

42. Banelli B, Forlani A, Allemanni G, Morabito A, Pistillo MP, Romani M, et al. MicroRNA in glioblastoma: An overview. Int J Genomics 2017;2017:7639084.

43. Candolfi M, Curtin JF, Nichols WS, Muhammad AG, King GD, Pluhar GE, et al. Intracranial glioblastoma models in preclinical neurooncology: Neuropathological characterization and tumor progression. J Neurooncol 2007;85:133-48.

44. Begicevic RR, Falasca M. ABC transporters in cancer stem cells: Beyond chemoresistance. Int J Mol Sci 2017;18:2362.

45. Kartal-Yandim M, Adan-Gokbulut A, Baran Y. Molecular mechanisms of drug resistance and its reversal in cancer. Crit Rev Biotechnol 2016;36:716-26.

46. Bonanni P, Levi M, Latham NB, Bechini A, Tiscione E, Lai P, et al. An overview on the implementation of HPV vaccination in Europe. Hum Vaccin 2011;7 Suppl:128-35.

47. Tierney B, Westin SN, Schlumbrecht MP, Ramirez PT. Early cervical neoplasia: Advances in screening and treatment modalities. Clin Adv Hematol Oncol 2010;8:547-55.

48. Masters JR. HeLa cells 50 years on: The good, the bad and the ugly. Nat Rev Cancer 2002;2:315-9.

49. Vertrees RA, Goodwin TJ, Jordan JM. Tissue culture models. In: Zanger DS, Popper HH, Jagirdar J, Haque AK, Cagle PT, Barrios R, editors. Molecular Pathology of Lung Diseases. New York: Springer Science and Business Media, LLC; 2008. p. 150-68. 